УДК 349.232:331.215.74:351.741(477)

DOI: https://doi.org/10.32631/pb.2020.3.08

\author{
МИКОЛА АНАТОЛІЙОВИЧ САМБОР, \\ кандидат юридичних наук, \\ член-кореспондент Національної академії наук вищої освіти України, \\ Прилуцький відділ поліції ГУнП в Чернігівській області; \\ https://orcid.org/0000-0002-0446-3892, \\ e-mail: nikolas783@ukr.net
}

\title{
ДОДАТКОВА ДОПЛАТА ДО ГРОШОВОГО ЗАБЕЗПЕЧЕННЯ ЯК СОЦІАЛЬНА ГАРАНТІЯ ПРАВ ПОЛІЦЕЙСЬКИХ ПІД ЧАС КАРАНТИНУ В УКРАЇНІ
}

\begin{abstract}
Досліджено особливості правового регулювання встановлення та виплати додаткової доплати до грошового забезпечення під час карантину для поліцейських. Проаналізовано нормативно визначені підстави для додаткової виплати фактичне обгрунтування застосування таких виплат для поліцейських. Обгрунтовано правову позицію щодо необхідності додаткових виплат для всіх поліцейських, враховуючи завдання, які стоять перед органами Національної поліції, та надання поліцейськими поліцейських послуг населенню України.
\end{abstract}

Ключові слова: карантин, поліція, додаткові доплати, грошове забезпечення, поліщейські послуги, правопорядок, життєзабезпечення.

Оригінальна стаття

\section{Постановка проблеми}

Україна проголошена як демократична, соціальна і правова держава, що має визначати вектори ії внутрішнього розвитку та зовнішніх відносин. Суб'єкти владних повноважень, які взяли на себе додаткові зобов'язання перед народом, що їх обрав, тим самим легітимувавши повноваження цих органів та їх посадових осіб, визнали за собою обов'язок гарантувати мінімально необхідні і достатні соціальні стандарти належних та безпечних умов проживання і праці українців.

Основними цілями соціальної держави є: максимальне задоволення постійно зростаючих матеріальних і духовних потреб членів суспільства в соціальній сфері; послідовне підвищення рівня життя населення та ліквідація соціальної нерівності; забезпечення загальної доступності основних соціальних благ, медичного і соціального обслуговування. Така держава повинна відкидати будь-які засоби досягнення цілей, що можуть порушити права інших громадян [1, с. 12]. Основними ознаками соціальної держави є: а) здійснення правового регулювання соціальної сфери, яке грунтується на загальнолюдських принципах соціальної справедливості, рівності і громадської солідарності та спрямоване на створення умов, необхідних для гідного життя і вільного розвитку кожної людини; б) наявність законодавчого підгрунтя для самостійного забезпечення працездатною людиною гідного життя для себе та своєї сім'ї; в) наявність державних ме- ханізмів підтримки непрацездатних осіб та осіб, які з об'єктивних причин не можуть забезпечити себе самостійно; г) наявність державних гарантій на гідний людини прожитковий мінімум, соціальне забезпечення, загальне покращення добробуту й інші соціально-економічні права громадян; г) реально діючий прозорий і зрозумілий механізм реалізації соціального захисту; д) всебічне забезпечення правових, економічних та організаційно-управлінських гарантій реалізації соціальних прав громадян; е) ужиття заходів щодо мінімізації соціально-економічного розмежування між людьми, зміцнення соціальної злагоди в суспільстві [1, с. 13].

Працездатність людини та можливість вибору розглядаються в такий спосіб рушійними силами реалізації права на працю. Можливість реалізації права на працю залежить від виконання найважливішої функції держави в цій сфері - створення умов, за яких право на працю стає реальним [2, с. 193-194]. Ми переконані, що забезпечення належних умов реалізації повноважень поліції є однією з умов ефективності впровадження низки функцій держави в суспільні відносини.

\section{Стан дослідження проблеми}

Питання трудових відносин та їх врегулювання засобами права були предметом досліджень юристів-науковців, серед яких слід згадати праці В. М. Андріїва, С. В. Венедіктова, М. І. Іншина, К. Ю. Мельника, Є. Ю. Подорожнього, 
А. М. Слюсар, В. І. Щербини, О. М. Ярошенка. Не стали виключенням дослідження правового регулювання трудових відносин працівників правоохоронних органів. Водночас правове регулювання трудових відносин поліцейських містить надзвичайно багато прогалин як законодавчого регулювання, так і доктринальних досліджень. Зумовлено це тим, що Національна поліція України, як орган виконавчої влади, $\epsilon$ новоствореним органом, а також тим, що більшість трудових відносин поліцейських залишаються неврегульованими на законодавчому рівні, а відомчі нормативні акти, які ухвалюються навздогін виникнення нових відносин, не вирізняються якістю нормативного матеріалу, що в них міститься, нівелюючи принципи правової визначеності, зрозумілості нормативного матеріалу. Особливо це стосується трудових відносин поліцейських в умовах загострення санітарно-епідемічної ситуації в Україні та світі, зумовленої поширенням гострої респіраторної хвороби COVID-19, спричиненої коронавірусом SARS-CoV-2, коли поліцейські виконують свої повноваження разом із лікарями та представниками інших професій у галузі надання адміністративних і соціальних послуг, перебуваючи на першій лінії інфекційних загроз.

\section{Мета і завдання дослідження}

Враховуючи наведене, метою нашої статті $\epsilon$ аналіз законодавства України щодо створення соціальних гарантій трудових прав поліцейських шляхом запровадження додаткових доплат до грошового забезпечення під час надання останніми поліцейських послуг в умовах запровадження карантину.

Мета дослідження досягається виконанням таких завдань: висвітлити джерела права, норми яких повинні врегульовувати трудові права поліцейських щодо надання ними поліцейських послуг населенню; дослідити ефективність відомчих норм і суб'єктів відомчої нормотворчості в забезпеченні прав і свобод поліцейських, створенні додаткових соціальних гарантій поліцейським, які виконують свої обов'язки в умовах карантину, шляхом надання додаткових доплат до грошового забезпечення; розкрити бачення суб'єктів відомчої правотворчості соціальних гарантій поліцейських в умовах карантину.

Наукова новизна дослідження полягає в комплексному дослідженні джерел правового регулювання суспільних відносин із забезпечення трудових і соціальних прав поліцейських в умовах карантину та їх застосування для регулювання реальних суспільних відносин із забезпечення соціальних прав і гарантій поліцейських.

\section{Виклад основного матеріалу}

Вітчизняне законодавство у сфері регулювання відносин за участі поліцейських, зокрема пов'язаних із реалізацією поліцейськими їх трудових і соціальних прав, характеризується тим, що переважна більшість указаних норм міститься в підзаконних нормативноправових актах, а суб'єкти їх ухвалення відстоюють не стільки права поліцейських, скільки інтереси цих державних органів влади.

С. М. Бортник доходить висновку, що служба в поліції $є$ особливим видом трудової діяльності, який потребує спеціального регулювання. Саме з цією метою було ухвалено низку підзаконних нормативно-правових актів, норми яких спрямовані на координування окремих питань роботи правоохоронців. Унаслідок різкої зміни законодавства та створення принципово нового органу - Національної поліції України - підзаконні джерела трудових прав поліцейських необхідно узгодити, тобто сформувати відповідність між підзаконною базою та законодавчою. Вагомою проблемою існуючої системи підзаконних нормативних актів $€$ ії фактична застарілість. Більшість норм регулюють відносини, що стосуються реорганізованих або взагалі неіснуючих сьогодні служб. Цей аспект суттєво погіршує роботу Національної поліції, що доводить необхідність його термінового виправлення. Всі правові норми підзаконних нормативних актів не $\epsilon$ систематизованими, тобто положення одних наказів і постанов суперечать іншим. Унаслідок цього на практиці службовці правоохоронного органу не можуть належним чином реалізувати свої правомочності $[3$, с. 3031]. Реалізація завдань, що стоять перед Національною поліцією України, пов'язана з наданням поліцейських послуг в умовах загострення санітарно-епідемічної ситуації в країні, здійснюється в умовах суттєво підвищеного ризику для життя і здоров'я поліцейських та необхідності створення належних умов праці та виконання обов'язків поліцейським з боку їх керівників, що визначено у ст. 3 Дисциплінарного статуту Національної поліції України ${ }^{1}$.

1 Про Дисциплінарний статут Національної поліції України : Закон України від 15.03.2018 № 2337-VIII // База даних (БД) «Законодавство України» / Верховна Рада (BP) України. URL: https://zakon.rada.gov.ua/laws/show/2337-19 (дата звернення: 27.08.2020). 
3 питань соціального захисту військовослужбовців і працівників органів правопорядку Конституційний Суд України також висловив юридичну позицію, згідно з якою «Конституція України виокремлює й інші категорії громадян України, які потребують додаткових гарантій держави, зокрема гарантій соціального захисту. До них насамперед належать громадяни, які відповідно до ст. 17 Конституції України перебувають на службі в органах, що забезпечують суверенітет і територіальну цілісність України, іï економічну та інформаційну безпеку» (абз. 1 п. 3 мотивувальної частини Рішення від 20 березня 2002 р. № 5рп/2002). Соціальні гарантії військовослужбовців і працівників правоохоронних органів випливають 3 характеру покладених на них службових обов'язків у зв'язку з виконанням державних функцій (абз. 11 п. 3 мотивувальної частини Рішення Конституційного Суду України від 17 березня 2004 р. № 7-рп/2004) ${ }^{1}$.

Національна поліція України - центральний орган виконавчої влади, який служить суспільству шляхом забезпечення охорони прав і свобод людини, протидії злочинності, підтримання публічної безпеки та порядку². Відповідно до ч. 1 ст. 59 Закону України «Про Національну поліцію» служба в поліції є державною службою особливого характеру, яка $\epsilon$ професійною діяльністю поліцейських з виконання покладених на поліцію повноважень ${ }^{3}$.

Юридична природа державної служби в органах поліції розкривається через її особливості, до яких запропоновано віднести: 1) особливість завдань, які поставлені перед службовцями органів поліції (забезпечення громадської безпеки і порядку, охорона прав та інтересів громадян); 2) можливість фінансування не тільки за рахунок коштів Державного бюджету, а й з інших джерел (плата за надані охоронні послуги); 3) особливий поря-

1 Рішення Першого Сенату Конституційного Суду України у справі за конституційною скаргою Зінченка Сергія Анатолійовича щодо відповідності Конституції України (конституційності) положень пункту 3 частини першої статті 97 Закону України «Про Національну поліцію» : від 22.04.2020 № 3-p(I)/2020 // БД «Законодавство України» / BP України. URL: https://zakon.rada.gov.ua/laws/show/va03p71020 (дата звернення: 13.08.2020).

2 Про Національну поліцію : Закон України від 02.07.2015 № 580-VIII // БД «Законодавство України» / ВР України. URL: https://zakon.rada.gov.ua/ laws/show/580-19 (дата звернення: 13.08.2020).

3 Там само. док формування органів поліції; 4) підставою для виникнення службово-трудових правовідносин в органах поліції, як правило, $є$ контрактна форма трудового договору; 5) службовці органів поліції мають право використовувати у своїй діяльності поліцейські засоби в порядку i в межах, визначених законодавством; 6) на службовців органів поліції поширюються особливі гарантії проходження служби [4, с. 7].

2020 р. уніс свої корективи в життя держав і суспільств, організацію та діяльність державних органів, що зумовлено поширенням гострої респіраторної хвороби COVID-19, спричиненої коронавірусом SARS-CoV-2. Так, Україна, як і інші держави світу, Рішенням Кабінету Міністрів України відповідно до норм Закону України «Про захист населення від інфекційних хвороб» запровадила на території України карантин, тобто адміністративні та медико-санітарні заходи, що застосовуються для запобігання поширенню особливо небезпечних інфекційних хвороб ${ }^{4}$ Рішень Кабінету Міністрів України було багато (від 11 березня 2020 р. № 211, від 16 березня 2020 р. № 215, від 20 травня 2020 р. № 392, від 25 червня 2020 р. № 522 , від 8 липня 2020 р. № 588 , від 22 липня 2020 р. № 641, від 12 серпня 2020 р. № 712, від 27 серпня 2020 р. № 757, від 26 серпня 2020 р. № 760, від 2 вересня 2020 р. № 791, від 9 вересня 2020 р. № 825, від 14 вересня 2020 р. № 846, від 16 вересня 2020 р. № 848, від 28 вересня 2020 р. № 888), але всі вони стосувалися запровадження карантину на території України та його особливостей в окремих регіонах.

Ураховуючи масштаби обставин, що сприяли ухваленню рішення про запровадження карантину в Україні, визначення необхідних профілактичних, протиепідемічних та інших заходів, їх виконавців, встановлення тимчасових обмежень прав фізичних і юридичних осіб та додаткових обов'язків, що покладаються на них, інших заходів, необхідних для запобігання поширенню коронавірусної інфекції, а також необхідності створення додаткових гарантій і умов захисту й охорони життя та здоров'я суб'єктів, на яких покладено повноваження з реалізації вказаних завдань, Кабінет Міністрів України 29 квітня 2020 р. ухвалив Постанову № 375, якою визначив, що на період карантину, установленого Кабінетом

4 Про захист населення від інфекційних хвороб : Закон України від 06.04.2000 № 1645-III // БД «Законодавство України» / ВP України. URL: https://zakon.rada.gov.ua/laws/show/1645-14 (дата звернення: 27.08.2020). 
Міністрів України з метою запобігання поширенню на території України гострої респіраторної хвороби COVID-19, спричиненої коронавірусом SARS-CoV-2, та протягом 30 днів з дня його відміни окремим категоріям працівників, зокрема таким як військовослужбовці Національної гвардії та Державної прикордонної служби, посадові особи Державної митної служби, особи рядового та начальницького складу органів і підрозділів цивільного захисту, поліцейські, які забезпечують життєдіяльність населення, що виявляється в забезпеченні продовольчими та непродовольчими товарами, послугами зв'язку, транспорту, адміністративними, соціальними послугами, а також захисті прав дітей і забезпечення правопорядку та безпеки громадян, і внаслідок виконання своїх обов'язків мають безпосередній контакт 3 населенням, встановлюється додаткова доплата до заробітної плати (грошового забезпечення) пропорційно відпрацьованому часу в зазначених умовах ${ }^{1}$. Кабінет Міністрів України визначив, що встановлення доплати, визначеної п. 1 цієї Постанови, працівникам підприємств, установ та організацій, органів державної влади, які фінансуються 3 державного та місцевих бюджетів, здійснюється у граничному розмірі до $50 \%$ заробітної плати (грошового забезпечення), а встановлення доплати, визначеної п. 1 цієї Постанови, працівникам надавачів соціальних послуг державного/комунального сектору, які безпосередньо надають соціальні послуги за місцем проживання/перебування їх отримувачів (вдома), здійснюється у граничному розмірі до $100 \%$ заробітної плати (грошового забезпечення). Перелік посад (професій) працівників, яким встановлюються такі доплати, визначається відповідним центральним органом виконавчої

1 Деякі питання оплати праці (грошового забезпечення) окремих категорій працівників, військовослужбовців Національної гвардії та Державної прикордонної служби, посадових осіб Державної митної служби, осіб рядового та начальницького складу органів і підрозділів цивільного захисту, поліцейських, які забезпечують життєдіяльність населення, на період дії карантину, установленого Кабінетом Міністрів України з метою запобігання поширенню на території України гострої респіраторної хвороби COVID-19, спричиненої коронавірусом SARS-CoV-2, та протягом 30 днів з дня його відміни : Постанова Кабінету Міністрів України від 29.04.2020 № 375 // БД «Законодавство України» / ВР України. URL: https://zakon.rada.gov.ua/laws/show/375-2020-п (дата звернення: 27.08.2020). влади у сфері, в якій він реалізує державну політику. Персональний перелік працівників, яким встановлюється доплата, визначається керівником (керівником державної служби) відповідного підприємства, установи або організації, органу державної влади. Доплати, визначені пунктами 2 і 3 Постанови Кабінету Міністрів України від 29 квітня 2020 р. № 375, здійснюються за рахунок і в межах видатків державного та місцевих бюджетів, передбачених за відповідними бюджетними програмами головних розпорядників бюджетних коштів ${ }^{2}$.

На вказані цілі Постановою Кабінету Міністрів України від 10 червня 2020 р. № 485 було виділено Міністерству внутрішніх справ 4680183,3 тис. грн, зокрема Апарату Міністерства внутрішніх справ - 171081,6 тис. грн, Національній гвардії - 125105,5 тис. грн, Адміністрації Державної прикордонної служби 103774,7 тис. грн, Державній службі з надзвичайних ситуацій - 51302,5 тис. грн, Національній поліції - 4228919 тис. грн на безповоротній основі (видатки споживання), із фонду боротьби з гострою респіраторною хворобою COVID-19, спричиненою коронавірусом SARS$\mathrm{CoV}-2$, та її наслідками для здійснення доплати до грошового забезпечення військовослужбовцям Національної гвардії та Державної прикордонної служби, особам рядового та начальницького складу органів і підрозділів цивільного захисту, поліцейським, які забезпечують життєдіяльність населення на період дії карантину, встановленого Кабінетом Міністрів України з метою запобігання поширенню на території України гострої респіраторної хвороби COVID-19, спричиненої коронавіруcom SARS-CoV-2, доплати до заробітної плати медичним та іншим працівникам, які безпосередньо зайняті на роботах з ліквідації захворювання на гостру респіраторну хворобу COVID-19, спричинену коронавірусом SARS$\mathrm{CoV}-2$, у відомчих закладах охорони здоров'я ${ }^{3}$.

2 Там само.

3 Про виділення коштів для здійснення доплати військовослужбовцям, особам рядового і начальницького складу, поліцейським, які забезпечують життєдіяльність населення, медичним та іншим працівникам, які безпосередньо зайняті на роботах з ліквідації захворювання на гостру респіраторну хворобу COVID-19, спричинену коронавірусом SARS-CoV-2, у відомчих закладах охорони здоров'я : Постанова Кабінету Міністрів України від 10.06.2020 № 485 // БД «Законодавство України» / BP України. URL: https://zakon.rada.gov.ua/laws/show/485-2020-п (дата звернення: 27.08.2020). 
Однак, як свідчить практика правозастосування, суб'єкти, уповноважені розпоряджатися вказаними коштами, намагаються обмежити коло суб'єктів, які мають право на таку додаткову соціальну гарантію, пов'язану із життєзабезпеченням населення в умовах карантину, незважаючи на те, що вони виконують завдання з реалізації карантинних заходів.

Так, Наказом МВС України «Про окремі питання організації оплати праці на період карантину» від 3 червня 2020 р. № 431 наказано керівнику Національної поліції України здійснити додаткову оплату у граничному розмірі до 50 \% заробітної плати (грошового забезпечення) пропорційно відпрацьованому часу в зазначених умовах. Водночас голова Національної поліції України своїм дорученням «Про організацію заходів, спрямованих на забезпечення встановлення додаткової оплати поліцейським, визначеної Постановою Кабінету Міністрів України від 29 квітня 2020 року № 375» від 25 червня 2020 р. № 7789/01/292020 передоручив визначити персональний перелік поліцейських, які забезпечували правопорядок і безпеку громадян й унаслідок виконання своїх обов'язків мали безпосередній контакт із населенням, та встановити додаткову доплату в граничному розмірі до $50 \%$ грошового забезпечення пропорційно відпрацьованому часу в особливих умовах. Забезпечити формування керівниками підпорядкованих підрозділів даних (погоджених із відповідними заступниками керівників органів та установ поліції за напрямком службової діяльності) щодо виконання підлеглими поліцейськими службових обов'язків на період дії карантину, встановленого Кабінетом Міністрів України з метою запобігання поширенню на території України гострої респіраторної хвороби COVID19, спричиненої коронавірусом SARS-CoV-2, без урахування періоду, протягом якого поліцейський перебував у відпустці, на навчанні, лікарняному (самоізоляції), був відсторонений від виконання службових обов'язків; пропорційності відпрацьованого часу (виконання службових обов'язків) поліцейськими в особливих умовах; розміру додаткової доплати в граничному розмірі до 50 \% грошового забезпечення пропорційно відпрацьованому часу в особливих умовах.

Аналіз відомчих нормативно-правових актів свідчить, що поліцейські, які виконували посадові обов'язки в умовах запровадженого карантину, мали б отримувати доплати залежно від місця контакту з населенням: 1) за місцем служби - до 50 \%; 2) за місцем проживання/перебування отримувачів послуг - до
100 \%. У Постанові Кабінету Міністрів України № 375 жодним чином не згадуються питання забезпечення правопорядку та безпеки громадян, а йдеться про надання відповідних послуг. Натомість Міністр внутрішніх справ України А. Б. Аваков, чітко дотримуючись положень Постанови Кабінету Міністрів України № 375, відтворив норми про встановлення додаткових фінансових гарантій - додаткової оплати праці поліцейських в умовах карантину, що створює додаткові загрози для життя і здоров'я поліцейських, лише з тим застереженням, що розмір додаткової оплати не повинен перевищувати 50 \% грошового забезпечення, хоча в Постанові Кабінету Міністрів України № 375 йдеться про дві категорії поліцейських, які мають право на $50 \%$ та $100 \%$ доплати до грошового забезпечення. У згаданому дорученні Національної поліції України № 7789/01/ 29-2020 безпідставно звужено коло суб'єктів, які мали право на такі доплати, визначено їх крізь призму суб'єктів, які виключно забезпечували правопорядок і безпеку громадян. Вважаємо, по-перше, такий контекст викладу норми в дорученні таким, що суперечить Наказу МВС України від 3 червня 2020 р. № 431 та приписам Постанови Кабінету Міністрів України 29 квітня 2020 р. № 375, з огляду на те, що в Постанові Кабінету Міністрів України йдеться про надання послуг населенню. Подруге, оплата здійснюється пропорційно відпрацьованому часу в умовах карантину, а не виконання обов'язків із забезпечення правопорядку і безпеки громадян. По-третє, центральні органи виконавчої влади в особі центрального органу управління поліцією намагаються максимально дистанціюватися від виконання прямих обов'язків щодо визначення вичерпного переліку осіб, які повинні надавати відповідні послуги, а не просто забезпечувати правопорядок. В умовах карантину постає питання не лише про здійснення контролю за встановленими обмеженнями, в тому числі обмеженнями прав і свобод фізичних або юридичних осіб, які, до речі, прямо не визначені в Законі України «Про Національну поліцію», інших законах України, що суперечить ст. 24 Закону України «Про Національну поліцію», адже покладає на поліцію додаткові обов'язки, а й про виконання власних повноважень поліції з реалізації завдань, що ставляться перед нею.

Крім того, неоднозначність у формулюванні норм позитивного права у відомчих нормативно-правових актах, а також наявність суттєвої розбіжності в їх правозастосуванні зумовлюють необхідність дослідження практики їх 
застосування, заснованої на тлумаченні норм, що містяться в постановах Кабінету Міністрів України, наказах Міністра внутрішніх справ України та дорученні Голови Національної поліції України, їх сприйняття керівництвом територіальних органів поліції, які є юридичними особами публічного права.

Йдеться про неофіційне тлумачення, яке полягає в тому, що: 1) інтерпретаційно-правова діяльність розглядається як опосередкована пізнавальна діяльність певних соціальних суб'єктів, яка виражається в певних об'єктивних формах; 2) відправною точкою цього пізнання в кінцевому підсумку є соціальне буття, внаслідок чого інтерпретація правової норми передбачає момент взаємозумовленості осягнення іï змісту тим соціальним середовищем, в якому ця норма виникла й інтерпретується; 3) на інтерпретаційно-правову діяльність поширюються загальнодіалектичні закономірності утворення і тлумачення текстів, проте норми права мають певну специфіку [5, с. 7] Таке дослідження консолідує доктринальне роз'яснення норм права та практику їх застосування, базується на знаннях і глибокому розумінні закономірностей правового регулювання, ролі права в організації суспільного життя, у вирішенні конкретних юридичних питань, і здійснюється особами, які займаються науковою діяльністю у сфері права. Спеціально-юридичне тлумачення - це тлумачення, що здійснюють особи, які займаються безпосередньо юридичною практичною діяльністю [5, с. 8]. Ми переконані, що об'єктивне застосування норм позитивного права учасниками правовідносин можливе за умови належного тлумачення норм права без будь-яких переваг, які можуть бути застосовані суб'єктами правозастосування, зокрема розпорядниками коштів, призначених для створення соціальних гарантій професійної діяльності поліцейських, які можуть використовувати свій розсуд на власне уподобання, в тому числі усупереч цінностям, сформованим у суспільстві, яке існує в умовах карантину.

Отже, дослідимо правову основу діяльності поліцейських, зокрема в умовах запровадження карантину.

У ст. 2 Закону України «Про Національну поліцію» визначено завдання поліції, якими є надання поліцейських послуг у сферах: 1) забезпечення публічної безпеки і порядку; 2) охорони прав і свобод людини, а також інтересів суспільства та держави; 3) протидії злочинності; 4) надання в межах, визначених законом, послуг з допомоги особам, які з особистих, економічних, соціальних причин або внаслідок надзвичайних ситуацій потребують такої допомоги 1 .

У своїй діяльності поліція керується Конституцією України, міжнародними договорами України, згода на обов'язковість яких надана Верховною Радою України, що втілює конституційні приписи, сформульовані у ст. 9 Конституції України, Законом України «Про Національну поліцію» та іншими законами України, актами Президента України та постановами Верховної Ради України, ухваленими відповідно до Конституції та законів України, актами Кабінету Міністрів України, а також виданими відповідно до них актами Міністерства внутрішніх справ України, іншими нормативно-правовими актами ${ }^{2}$, що, по суті, демонструє ієрархію нормативних актів, які можуть містити норми, що врегульовують поведінку поліції в суспільних відносинах. Зазначена норма $є$ логічним продовженням конституційних норм прямої дії, викладених у статтях 6, 19 Конституції України, де зазначається, що органи державної влади, їх посадові особи зобов'язані діяти лише на підставі, в межах повноважень та у спосіб, передбачені Конституцією та законами України ${ }^{3}$.

Ефективність діяльності поліцейських багато в чому залежить від умов здійснення такої діяльності [6, с. 157] та виконання повноважень поліції з надання поліцейських послуг. Умовою, яка істотно впливає на надання поліцейських послуг, є карантин, зумовлений поширенням гострої респіраторної хвороби COVID-19, спричиненої коронавірусом SARSCoV-2.

За даними Центру громадського здоров’я, станом на 28 вересня 2020 р. в Україні зафіксовано 2671 новий випадок коронавірусної хвороби COVID-19. Кількість активних хворих становить 108856 осіб. Загалом в Україні 201305 лабораторно підтверджених випадків COVID-19, із них 3996 летальних, 88453 пацієнти одужали. Проведено 2226508 тестувань методом ПЛР 4 . На жаль, статистика захворюваності на

1 Про Національну поліцію : Закон України від 02.07.2015 № 580-VIII // БД «Законодавство України» / ВР України. URL: https://zakon.rada.gov.ua/ laws/show/580-19 (дата звернення: 13.08.2020).

2 Там само.

3 Конституція України : Закон України від 28.06.1996 № 254к/96-ВР // БД «Законодавство України» / BP України. URL: https://zakon.rada.gov.ua/laws/show/254к/96-вр (дата звернення: 03.09.2020).

${ }_{4}^{4}$ Оперативна інформація про поширення коронавірусної інфекції 2019-nCoV // Міністерство 
COVID-19 серед поліцейських не ведеться, а поліцейські перш за все люди, які зазнають таких само ризиків, а виходячи з кола спілкування, відсутності можливості застосування до них карантинних заходів, пов'язаних з обмеженням кола спілкування, що суттєво впливає на можливість передачі коронавірусної хвороби, набувають додаткових факторів ризику захворіти на COVID-19.

єдиним завданням Національної поліції $\epsilon$ надання поліцейських послуг споживачам таких послуг.

Підходячи в системному розумінні та цілісності до поняття послуги, адміністративної послуги та поліцейської послуги, слід зазначити, що поняття послуги розкривається в цивільному законодавстві. Відповідно до ст. 901 Цивільного кодексу України за договором про надання послуг одна сторона (виконавець), якою у відносинах з надання поліцейських послуг є поліція та її посадові особи, зобов'язується за завданням другої сторони (замовника) - суспільства, окремих його членів, у тому числі об'єднань, надати послугу, яка споживається у процесі вчинення певної дії або здійснення певної діяльності, а замовник зобов'язується оплатити виконавцеві (з використанням зазначеної послуги, якщо інше не встановлено договором) ${ }^{1}$.

Ще одним законодавчим актом, який розкриває поняття «послуга», закріплюючи його легальне визначення, є Закон України «Про адміністративні послуги»2. Дія норм Закону України «Про адміністративні послуги» поширюється на суспільні відносини, пов'язані 3 наданням адміністративних послуг (за винятком дізнання, досудового слідства, оперативно-розшукової діяльності відповідно до ч. 2 ст. 2 Закону України «Про адміністративні послуги»). Отже, можна зробити висновок, що норми Закону України «Про адміністративні послуги» врегульовують суспільні відносини з

охорони здоров'я України : офіц. сайт. URL: https://www.kmu.gov.ua/news/operativnainformaciya-pro-poshirennya-koronavirusnoyiinfekciyi-2019-ncov-28-09-20 (дата звернення: 28.09.2020).

${ }^{1}$ Цивільний кодекс України : Закон України від 16.01.2003 № 435-IV // БД «Законодавство України» / ВР України. URL: https://zakon.rada.gov.ua/ laws/show/435-15 (дата звернення: 28.08.2020).

2 Про адміністративні послуги : Закон України від 06.09.2012 № 5203-VI // БД «Законодавство України» / BP України. URL: https://zakon.rada.gov.ua/laws/show/5203-17 (дата звернення: 28.08.2020). надання поліцейських послуг за винятком тих, що перераховані вище та прямо визначені у законі. Ураховуючи викладене, вважаємо, що поліцейські послуги є складовою адміністративних послуг, тому володіють всіма ознаками послуги. Отже, надання поліцейських послуг залежно від повноважень структурних підрозділів поліції та службових обов'язків (повноважень) здійснюється кожним поліцейським і передбачає наявність відносин, урегульованих нормами права, що прямо вказує на наявність контакту з громадянами, в тому числі іншими поліцейськими.

У нашому випадку є замовник (суспільство) та виконавець (Національна поліція). I, відповідно, обов'язково мають бути дотримані всі законодавчо визначені складові, що супроводжують поняття послуги [7, с. 22].

I. В. Клименко зазначив, що для поліцейських спілкування $\epsilon$ інструментом виконання функціональних обов'язків і основним засобом реалізації всіх сторін правоохоронної діяльності [8, с. 4].

У системному розумінні поліцейська послуга - це процес і результат здійснення владних повноважень суб'єктом надання одного 3 видів адміністративних послуг - Національною поліцією України в цілому та її органами, підрозділами і окремими поліцейськими за заявою фізичної або юридичної особи, спрямований на набуття, зміну чи припинення, а також поновлення прав та/або обов'язків такої особи відповідно до закону.

Сторонами надання поліцейських послуг $\epsilon$ виконавець (поліцейський) та замовник (фізична або юридична особа, в тому числі суспільство і держава).

Статтею 17 Закону України «Про Національну поліцію» визначено, що поліцейським $\epsilon$ громадянин України, який склав Присягу поліцейського, проходить службу на відповідних посадах у поліції і якому присвоєно спеціальне звання поліції ${ }^{3}$. Поліцейські проходять службу в центральному органі управління поліції, територіальних і міжрегіональних органах поліції. Незважаючи на те, що кожному структурному підрозділу Національної поліції України, окремим поліцейським притаманні свої завдання, функції та повноваження (права й обов'язки), форми та методи діяльності, вони здійснюють свої повноваження з метою реалізації завдань, які стоять перед Національною

3 Про Національну поліцію : Закон України від 02.07.2015 № 580-VIII // БД «Законодавство України» / ВР України. URL: https://zakon.rada.gov.ua/ laws/show/580-19 (дата звернення: 13.08.2020). 
поліцією України - надання поліцейських послуг у відповідних сферах, визначених у ст. 2 Закону України «Про Національну поліцію». Таке розмежування функцій підрозділів Національної поліції та окремих поліцейських забезпечує ефективну реалізацію поліцейських послуг в їх єдності.

На наш погляд, ефективне надання поліцейських послуг можливе виключно в умовах дотримання принципу законності та верховенства права, а також дотримання прав і свобод усіх без винятку учасників суспільних відносин з надання поліцейських послуг, зокрема поліцейських.

Поліцейські надають поліцейські послуги у межах повноважень, якими вони наділені відповідно до Закону України «Про Національну поліцію», що також деталізовані та конкретизовані у відомчих нормативно-правових актах.

Одними 3 ключових відомчих нормативно-правових актів, які поряд з Конституцією та законами України регламентують надання поліцейських послуг поліцейськими підрозділів моніторингу й організаційно-аналітичного забезпечення та оперативного реагування, $\epsilon$ накази MBC України «Про затвердження Порядку ведення єдиного обліку в органах (підрозділах) поліції заяв і повідомлень про кримінальні правопорушення та інші події» від 8 лютого 2019 р. № 100ㄹ, «Про затвердження Інструкції з організації діяльності чергової служби органів (підрозділів) Національної поліції України» від 23 травня 2017 р. № $440^{2}$, «Про затвердження Інструкції 3 організації реагування на заяви та повідомлення про кримінальні, адміністративні правопорушення або події та оперативного інформування в органах (підрозділах) Національної поліції України» від 16 лютого 2018 р. № $111^{3}$ (чин-

1 Про затвердження Порядку ведення єдиного обліку в органах (підрозділах) поліції заяв і повідомлень про кримінальні правопорушення та інші події : Наказ МВС України від 08.02.2019 № 100 // БД «Законодавство України» / ВР України. URL: https://zakon.rada.gov.ua/laws/show/ z0223-19 (дата звернення: 03.09.2020).

2 Про затвердження Інструкції з організації діяльності чергової служби органів (підрозділів) Національної поліції України : Наказ МВС України від 23.05.2017 № 440 // БД «Законодавство України» / ВР України. URL: https://zakon.rada.gov.ua/ laws/show/z0750-17 (дата звернення: 03.09.2020).

3 Про затвердження Інструкції з організації реагування на заяви та повідомлення про кримінальні, адміністративні правопорушення або події та оперативного інформування в органах ний на час досліджуваних правовідносин), «Про затвердження Інструкції 3 організації реагування на заяви і повідомлення про кримінальні, адміністративні правопорушення або події та оперативного інформування в органах (підрозділах) Національної поліції України» від 27 квітня 2020 р. № 3574, «Про затвердження Порядку розгляду звернень та організації проведення особистого прийому громадян в органах та підрозділах Національної поліції України» від 15 листопада 2017 р. № 9305, «Про затвердження Інструкції із заходів безпеки при поводженні зі зброєю» від 1 лютого 2016 р. № 706, «Про затвердження Порядку застосування електронних засобів контролю» від 8 червня 2017 р. № 4807, «Про затвердження Інструкції про порядок виконання органами Національної поліції ухвал слідчого судді, суду про обрання запобіжного заходу у вигляді домашнього арешту та про зміну раніше обраного запобіжного заходу на запобіжний захід у вигляді домашнього арешту» від 13 липня 2016 р. № 6548, «Про затвердження

(підрозділах) Національної поліції України : Наказ МВС України від 16.02.2018 № 111 // БД «Законодавство України» / BP України. URL: https://zakon.rada.gov.ua/laws/show/z0371-18 (дата звернення: 03.09.2020). Втратив чинність.

4 Про затвердження Інструкції з організації реагування на заяви і повідомлення про кримінальні, адміністративні правопорушення або події та оперативного інформування в органах (підрозділах) Національної поліції України : Наказ МВС України від 27.04.2020 № 357 // БД «Законодавство України» / BP України. URL: https://zakon.rada.gov.ua/laws/show/z0443-20 (дата звернення: 03.09.2020).

5 Про затвердження Порядку розгляду звернень та організації проведення особистого прийому громадян в органах та підрозділах Національної поліції України : Наказ МВС України від 15.11.2017 № 930 // БД «Законодавство України» / BP України. URL: https://zakon.rada.gov.ua/laws/ show/z1493-17 (дата звернення: 03.09.2020).

6 Про затвердження Інструкції із заходів безпеки при поводженні зі зброєю : Наказ МВС України від 01.02.2016 № 70 // БД «Законодавство України» / BP України. URL: https://zakon.rada.gov.ua/laws/show/z0250-16 (дата звернення: 03.09.2020).

7 Про затвердження Порядку застосування електронних засобів контролю : Наказ МВС України від 08.06.2017 № 480 // БД «Законодавство України» / ВР України. URL: https://zakon.rada.gov.ua/ laws/show/z0860-17 (дата звернення: 03.09.2020).

8 Про затвердження Інструкції про порядок виконання органами Національної поліції ухвал 
Інструкції з організації контролю за виконанням документів у Національній поліції України» від 13 червня 2016 р. № 5031', «Про затвердження Інструкції з організації та проведення перевірок службової діяльності органів (підрозділів) Національної поліції» від 30 січня 2017 p. № 672, «Про затвердження Правил етичної поведінки поліцейських» від 9 листопада 2016 р. № 11793, «Про затвердження $\mathrm{IH}^{-}$ струкції про порядок переведення органів Національної поліції України на посилений варіант службової діяльності» від 10 грудня 2015 р. № 15604, накази Національної поліції України «Про затвердження Переліку правопорушень та подій, інформація про які подається до центрального органу управління поліції, головних управлінь Національної поліції в Автономній Республіці Крим та м. Севастополі, областях та м. Києві» від 4 липня 2018 р. № 6455 , «Про затвердження Інструкції з орга-

слідчого судді, суду про обрання запобіжного заходу у вигляді домашнього арешту та про зміну раніше обраного запобіжного заходу на запобіжний захід у вигляді домашнього арешту : Наказ МBC України від 13.07.2016 № 654 // БД «Законодавство України» / BP України. URL: https://zakon.rada.gov.ua/laws/show/z1087-16 (дата звернення: 03.09.2020).

${ }^{1}$ Про затвердження Інструкції з організації контролю за виконанням документів у Національній поліції України : Наказ МВС України від 13.06.2016 № 503 // БД «Законодавство України» / BP України. URL: https://zakon.rada.gov.ua/laws/ show/z0944-16 (дата звернення: 03.09.2020).

2 Про затвердження Інструкції з організації та проведення перевірок службової діяльності органів (підрозділів) Національної поліції : Наказ МВС України від 30.01.2017 № 67 // БД «Законодавство України» / BP України. URL: https://zakon.rada.gov.ua/laws/show/z0304-17 (дата звернення: 03.09.2020).

3 Про затвердження Правил етичної поведінки поліцейських : Наказ МВС України від 09.11.2016 № 1179 // БД «Законодавство України» / BP України. URL: https://zakon.rada.gov.ua/laws/ show/z1576-16 (дата звернення: 03.09.2020).

${ }^{4}$ Про затвердження Інструкції про порядок переведення органів Національної поліції України на посилений варіант службової діяльності : Наказ МВС України від 10.12.2015 № 1560 // БД «Законодавство України» / BP України. URL: https://zakon.rada.gov.ua/laws/show/z0012-16 (дата звернення: 03.09.2020).

5 Про затвердження Переліку правопорушень та подій, інформація про які подається до центрального органу управління поліції, головних управлінь Національної поліції в Автоном- нізації планування в системі Національної поліції України» від 24 грудня 2015 р. № 2026, у тому числі Наказу МВС України «Про затвердження Типового положення про управління організаційно-аналітичного забезпечення та оперативного реагування головних управлінь Національної поліції України в Автономній Республіці Крим та м. Севастополі, областях, м. Києві» від 22 січня 2016 р. № 39, де зазначається, що відповідно до законів України «Про центральні органи виконавчої влади», «Про Національну поліцію», Положення про Національну поліцію, затвердженого Постановою Кабінету Міністрів України від 28 жовтня 2015 р. № 877, Положення про Міністерство внутрішніх справ України, затвердженого Постановою Кабінету Міністрів України від 28 жовтня 2015 р. № 878 поліцейські, наприклад посадові особи секторів моніторингу (як підрозділів УОАЗОР на місцях) здійснюють координацію, аналіз, планування, контроль та узгодження діяльності структурних підрозділів апарату головного управління та відокремлених структурних підрозділів головного управління з питань забезпечення публічної безпеки і порядку, охорони прав і свобод людини, інтересів суспільства і держави, протидії злочинності, а також надання в межах, визначених законом, послуг з допомоги особам, які з особистих, економічних, соціальних причин або внаслідок надзвичайних ситуацій потребують такої допомоги (далі - поліцейські послуги), організації та проведення заходів щодо рятування людей, забезпечення їх безпеки, охорони майна в разі стихійного лиха, аварій, пожеж, катастроф та ліквідації їх наслідків (далі - цивільний захист), участь в організації діяльності оперативних штабів, ситуаційних центрів/відділів, робочих груп з координації дій та управління силами і засобами поліції під час проведення масових заходів, державних свят і надзвичайних подій ${ }^{7}$ тощо. Очевидно, що

ній Республіці Крим та м. Севастополі, областях та м. Києві : Наказ Голови Нац. поліції України від 04.07.2018 № 645 // Tranzit : сайт. URL: http://tranzit.ltd.ua/nakaz/ (дата звернення: 03.09.2020).

6 Про затвердження Інструкції з організації планування в системі Національної поліції України : Наказ Голови Нац. поліції України від 24.12.2015 № 202 // Tranzit : сайт. URL: http://tranzit.ltd.ua/nakaz/ (дата звернення: 03.09.2020).

7 Про затвердження Типового положення про управління організаційно-аналітичного забезпечення та оперативного реагування головних 
згадані підрозділи моніторингу й організаційно-аналітичного забезпечення та оперативного реагування територіальних і структурних підрозділів Національної поліції надають поліцейські послуги, спрямовані на реалізацію завдань, згаданих у ст. 2 Закону України «Про Національну поліцію».

У цілому поліцейські як посадові особи Національної поліції України повинні мати однаковий правовий статус поліцейського, який характеризується не лише сукупністю прав і обов'язків, а й єдністю соціальних гарантій їх захисту, а обов'язки, які додатково покладаються на поліцейських, повинні компенсуватися відповідним соціальним захистом 3 боку держави.

У зв'язку із запровадженим на підставі ст. 29 Закону України «Про захист населення від інфекційних хвороб» карантину з метою запобігання поширенню на території України гострої респіраторної хвороби COVID-19, спричиненої коронавірусом SARS-CoV-2, з урахуванням рішення Державної комісії з питань техногенно-екологічної безпеки та надзвичайних ситуацій у період з 12 березня 2020 р. фактично до сьогодні робота поліцейських здійснювалася відповідно до норм Закону України «Про Національну поліцію», Положення про Національну поліцію, затвердженого Постановою Кабінету Міністрів України від 28 жовтня 2015 р. № 877, положень про територіальні та структурні підрозділи поліції, указів Президента України та постанов Кабінету Міністрів України щодо запровадження на території України надзвичайної ситуації та встановлення карантину, а також норм Кодексу цивільного захисту України, інших нормативно-правових актів, пов'язаних із виконанням аварійно-рятувальних робіт ланок цивільного захисту, в тому числі охорони публічного порядку, а також відповідно до Наказу Голови Національної поліції від 17 березня 2020 р. та наказів керівників Головних управлінь Національної поліції в областях щодо введення посиленого режиму службової діяльності підрозділів ГУнП областей, а також функціональних обов'язків поліцейських (усіх без винятку, незалежно від їх посад) громадянам надавалися поліцейські послуги із: забезпечення публічної безпеки та порядку; охоро-

управлінь Національної поліції України в Автономній Республіці Крим та м. Севастополі, областях, м. Києві : Наказ МВС України від 22.01.2016 № 39 // БД «Законодавство України» / ВР України. URL: https://zakon.rada.gov.ua/laws/show/ z0216-16 (дата звернення: 03.09.2020). ни прав і свобод людини, а також інтересів суспільства і держави; протидії злочинності; надання в межах, визначених законом, послуг з допомоги особам, які з особистих, економічних, соціальних причин або внаслідок надзвичайних ситуацій потребують такої допомоги 1 .

Насамперед слід зауважити, що в деяких ГУНП продовжується безпідставне дублювання наказів МВС України чи центрального органу управління Національної поліції. Прикладом цього $€$ запровадження Наказом Голови Національної поліції України посиленого варіанта службової діяльності для всіх органів та підрозділів поліції, який системно своїми наказами продублювали керівники ГУНП областей. Зазначене створює враження, що накази Голови Національної поліції України не поширюються на юридичних осіб публічного права, якими є Головні управління Національної поліції в областях. Слід звернути увагу на те, що керівництво ГУНП областей не має права запроваджувати посилений варіант службової діяльності на строки, на які має право це робити Голова Національної поліції України.

Як результат, поліцейські у вказаний період виконували комплекс організаційно-правових, превентивних, профілактичних, оперативних та інших заходів, пов'язаних 3 особливим режимом виконання службових завдань і залученням значної кількості поліцейських з метою швидкої стабілізації оперативної обстановки ${ }^{2}$, оскільки керівництвом ГУНП областей було визначено, що в повсякденному режимі несення служби їх виконати неможливо. Поліцейські виконували функціональні обов'язки безпосередньо на службі, дистанційної форми виконання службових обов'язків у територіальних підрозділах практично не застосовувалося, поліцейським сектора було заборонено брати відпустки. У комплексі завдань із забезпечення посиленого варіанта, виконання функціональних обов'язків в умовах надзвичайної ситуації, а також посиленого варіанта несення служби передбачалося виконання низки заходів, передбачених

1 Про Національну поліцію : Закон України від 02.07.2015 № 580-VIII // БД «Законодавство України» / ВР України. URL: https://zakon.rada.gov.ua/ laws/show/580-19 (дата звернення: 13.08.2020).

2 Про затвердження Інструкції про порядок переведення органів Національної поліції України на посилений варіант службової діяльності : Наказ МВС України від 10.12.2015 № 1560 // БД «Законодавство України» / BP України. URL: https://zakon.rada.gov.ua/laws/show/z0012-16 (дата звернення: 03.09.2020). 
Наказом МВС України від 10 грудня 2015 р № 1560, адже на території обслуговування підрозділу поліції був уведений посилений варіант службової діяльності, що передбачав: тимчасову відміну вихідних днів для поліцейських і відкликання їх із відпусток; припинення здійснення відряджень або відкликання з них поліцейських; установлення для поліцейських (крім добових нарядів) несення служби понад установлену тривалість робочого часу, а також у вихідні та святкові дні, але не більше 12-годинного робочого дня та шестиденного робочого тижня ${ }^{1}$ (підтверджується службовими телеграмами ГУНП в Чернігівській області).

Крім того, внаслідок запровадження карантину поліцейські виконували завдання із вжиття заходів, спрямованих на забезпечення дотримання карантинних обмежень. Зазначене здійснювалося шляхом обмеження низки соціально-трудових прав поліцейських, зокрема їх права на відпочинок і відпустки.

За вказаний період поліцейські виконували службові обов'язки відповідно до їх розподілу, зокрема розгляд звернень громадян, здійснення контролю за дотриманням законодавства про звернення громадян, проведення службових розслідувань, здійснення обліку матеріалів, розроблення, підготовку та впровадження службових документів, що включали в себе безпосередній контакт із населенням поліцейських, здійснювали опитування осіб (поліцейських, а також інших осіб), які володіли інформацією, необхідною для виконання службових обов'язків, у тому числі за місцем проживання вказаних осіб, здійснювали виїзди до населених пунктів, які входять до території обслуговування, де контактували 3 місцевими мешканцями, працівниками інших правоохоронних органів, зокрема прокуратури, під час здійснення контролю за законодавством про звернення громадян, 3 працівниками ДСНС, а також медичними працівниками під час проведення звірок обліку фактів звернення та доставлення до закладів охорони здоров'я осіб у зв'язку із заподіянням їм тілесних ушкоджень кримінального характеру та інформування про такі випадки органів і підрозділів поліції 2 , проведення яких ви-

\footnotetext{
1 Там само.

2 Про порядок обліку фактів звернення та доставлення до закладів охорони здоров'я осіб у зв'язку із заподіянням їм тілесних ушкоджень кримінального характеру та інформування про такі випадки органів і підрозділів поліції : Наказ MBC України та МО3 України від 06.07.2016 № 612/679 // БД «Законодавство України» / ВР
}

значено завданням перед органами Національної поліції, контактували із медичними закладами, підрозділами екстреної медичної допомоги щодо узгодження заходів із запобігання поширенню коронавірусної інфекції, підготовки та надання відповідних відомостей до ГУНП областей щодо наявності матеріальних резервів з виконання медичними працівниками їх обов'язків з надання медичної допомоги хворим на COVID-19, з фізичними особами та посадовими особами підприємств, установ і організацій, брали участь у роботі засідань ТЕБ та НС, спрямованих на забезпечення сталого життєзабезпечення мешканців територіальної громади в умовах поширення на території України гострої респіраторної хвороби COVID-19, спричиненої коронавіруcom SARS-CoV-2, тощо. Крім цього, поліцейські забезпечували публічний порядок та безпеку під час релігійних свят (Великдень, поминальні дні, Трійця тощо), під час зібрань громадян у населених пунктах регіону, де загострювалася оперативна обстановка та виникала необхідність у підтриманні правопорядку. Також забезпечували охорону публічного порядку та безпеку на блок-постах, у ході запровадження карантинних обмежень під час обмеження в'їзду-виїзду в населені пункти, де виник спалах коронавірусної інфекції, а також у закладі охорони здоров'я, визначеної як лікарня, де надавалися медичні послуги хворим на коронавірус. Поліцейські здійснювали перевірку несення служби на блок-постах та в лікарнях, унаслідок чого контактували з лікарями, медичним персоналом та громадянами, в тому числі іншими службами, які забезпечували життєдіяльність, здійснювали управління силами та засобами реагування патрульної поліції, інших підрозділів, задіяних для підтримання публічної безпеки і порядку на місцях несення служби під час карантинних заходів, зокрема у відпрацюваннях об'єктів, які згідно з видом своєї діяльності пов'язані 3 прийманням відвідувачів, брали участь у роботі всеукраїнських заходів, де розглядалися питання виконання повноважень поліції в умовах надзвичайної ситуації та запровадження карантину. Встановлювали запобіжні заходи у вигляді домашнього арешту, в тому числі із застосуванням електронних засобів контролю, що вимагало виїзду до місця проживання або перебування підозрюваних та обвинувачених. Виконання вказаних повноважень неможливо без особистого та безпосереднього

України. URL: https://zakon.rada.gov.ua/laws/ show/z1051-16 (дата звернення: 03.09.2020). 
контакту з підозрюваними, обвинуваченими їх представниками та захисниками. Унаслідок реалізації вказаних заходів, спрямованих на надання поліцейських послуг, поліцейським доводиться щоденно контактувати з громадянами, які можуть бути хворими на гостру респіраторну хворобу COVID-19, спричинену коронавірусом SARS-CoV-2, оскільки офіційних заборон прийняття громадян та надання їм поліцейських послуг не було, так само, як не було й обов'язку таких громадян проходити відповідний тест перед зверненням до поліцейських. Відвідували за місцем проживання сім'ї працівників поліції, що вимагається керівництвом підрозділів поліції, надавали допомогу людям, які її потребували та перебували в зоні ризику зараження коронавірусної інфекції (особи, старші за 60-65 років), виконуючи, в тому числі, вимоги службових листів ГУНП областей, наприклад відвідування ветеранів напередодні святкування 9 травня тощо.

Надавалися поліцейські послуги громадянам, які зверталися до поліцейських за допомогою, зокрема за наданням копій відповідей за їх попередніми зверненнями, а також ознайомлення з указаними матеріалами та їх копіюванням. Контактування з указаними особами відбувалося за місцем служби.

Крім того, слід зауважити, що щоденна професійна робота поліцейських пов'язана з наданням поліцейських послуг, контактуванням 3 іншими поліцейськими, посадовими особами органів державної влади та місцевого самоврядування, населенням, що входять до обслуговування підрозділу поліції, в тому числі за місцем проживання таких громадян або за місцем розташування (перебування) юридичних та фізичних осіб, перебуванням у публічних місцях тощо, в тому числі під час руху на службу у спеціальних нерегулярних перевезеннях, організованих органами місцевого самоврядування для посадових осіб ДСНС, поліції та закладів охорони здоров'я, які забезпечували життєдіяльність міста в період карантину, де має місце контакт з громадянами.

Відтак за специфікою роботи поліцейські контактують 3 іншими поліцейськими, які за особливостями виконання їх обов'язків контактують з особами, які були визначені як «контакні», а також з підозрою на коронавірусну інфекцію або прибули з регіонів, у яких склалася критична ситуація 3 поширенням коронавірусу.

Нормами Постанови Кабінету Міністрів України «Деякі питання оплати праці (грошового забезпечення) окремих категорій працівників, військовослужбовців Національної гвардії та Державної прикордонної служби, посадових осіб Державної митної служби, осіб рядового та начальницького складу органів і підрозділів цивільного захисту, поліцейських, які забезпечують життєдіяльність населення, на період дії карантину, установленого Кабінетом Міністрів України з метою запобігання поширенню на території України гострої респіраторної хвороби COVID-19, спричиненої коронавірусом SARS-CoV-2, та протягом 30 днів 3 дня його відміни» від 29 квітня 2020 р. № 375 установлено, що на період карантину, установленого Кабінетом Міністрів України 3 метою запобігання поширенню на території України гострої респіраторної хвороби COVID19, спричиненої коронавірусом SARS-CoV-2, та протягом 30 днів з дня його відміни окремим категоріям працівників, військовослужбовців Національної гвардії та Державної прикордонної служби, посадових осіб Державної митної служби, осіб рядового та начальницького складу органів і підрозділів цивільного захисту, поліцейських, які забезпечують життєдіяльність населення (забезпечення продовольчими та непродовольчими товарами, послугами зв'язку, транспорту, адміністративними, соціальними послугами, а також захист прав дітей та забезпечення правопорядку і безпеки громадян) та внаслідок виконання своїх обов'язків мають безпосередній контакт з населенням, встановлюється додаткова доплата до заробітної плати (грошового забезпечення) пропорційно відпрацьованому часу в зазначених умовах ${ }^{1}$.

Визначено, що життєдіяльність - це повсякденна діяльність, здатна забезпечити людині їі існування, існування інших членів суспільства та всього суспільства в цілому шляхом навчання, спілкування, орієнтації,

1 Деякі питання оплати праці (грошового забезпечення) окремих категорій працівників, військовослужбовців Національної гвардії та Державної прикордонної служби, посадових осіб Державної митної служби, осіб рядового та начальницького складу органів і підрозділів цивільного захисту, поліцейських, які забезпечують життєдіяльність населення, на період дії карантину, установленого Кабінетом Міністрів України з метою запобігання поширенню на території України гострої респіраторної хвороби COVID-19, спричиненої коронавірусом SARS-CoV-2, та протягом 30 днів 3 дня його відміни : Постанова Кабінету Міністрів України від 29.04.2020 № 375 // БД «Законодавство України» / ВР України. URL: https://zakon.rada.gov.ua/laws/show/375-2020-п (дата звернення: 27.08.2020). 
пересування, самообслуговування, контролю за своєю поведінкою, участі у трудовій діяльності $^{1}$. Життєдіяльність - це повсякденна діяльність, здатність організму особи здійснювати діяльність у спосіб і в межах, звичайних для людини ${ }^{2}$. Життєдіяльність являє собою інтеграцію фізичних, психологічних та соціальних функцій людини, вказує на те, що діяльність поліцейських, які обіймають відповідні посади 3 виконання своїх функцій, спрямованих на надання вичерпного переліку поліцейських послуг, а також їх участь у роботі комісій ТЕБ та НС та Тр0, вказує на забезпечення життєдіяльності як підрозділу поліції щодо виконання ним повноважень, спрямованих на реалізацію завдань Національної поліції в регіоні, а також на забезпечення умов існування населення міста та районів.

Поняття «населення» означає національне, регіональне та місцеве населення в його звичайному місці проживання на референтну дату (пункт «а» ст. 2 Регламенту Європейського Парламенту і Ради (ЄC) № 763/2008 від 9 липня 2008 р. про переписи населення та житлового фонду3). Населення - це особи, які проживають, працюють або тимчасово знаходяться поблизу (Наказ М03 України «Про затвердження державних санітарних правил та норм» від 1 серпня 1996 р. № 2394). Вказане дозволяє дійти висновку, що під час виконання службових обов'язків із надання поліцейських послуг поліцейські безпосередньо спілкувалися з населенням.

На жаль, у чинному законодавстві України відсутнє визначено поняття «правопорядок»,

1 Про затвердження Інструкції про встановлення груп інвалідності : Наказ МОЗ України від 07.04.2004 № 183 // БД «Законодавство України» / ВР України. URL: https://zakon.rada.gov.ua/ laws/show/z0516-04 (дата звернення: 30.08.2020). Втратив чинність.

2 Про реабілітацію осіб з інвалідністю в Україні : Закон України від 06.10.2005 № 2961-IV // БД «Законодавство України» / ВP України. URL: https://zakon.rada.gov.ua/laws/show/2961-15 (дата звернення: 30.08.2020)

3 Регламент Європейського Парламенту i Ради (ЄС) № 763/2008 від 9 липня 2008 року про переписи населення та житлового фонду // БД «Законодавство України» / BP України. URL: https://zakon.rada.gov.ua/laws/show/984_006-08 (дата звернення: 30.08.2020).

4 Про затвердження державних санітарних правил та норм : Наказ МО3 України від 01.08.1996 № 239 // БД «Законодавство України» / BP України. URL: https://zakon.rada.gov.ua/laws/ show/z0488-96 (дата звернення: 30.08.2020). тоді як МВС України свого часу тлумачило його як систему суспільних відносин, врегульованих нормами права 5 . Це підтверджує, що поліцейські $\epsilon$ учасниками суспільних відносин, а відтак мають контакт із населенням.

Ураховуючи викладене, слід зробити однозначний висновок, що поліцейські під час виконання службових обов'язків спрямували свою діяльність на забезпечення врегулювання нормами позитивного права суспільних відносин, що мали місце на території обслуговування підрозділу поліції.

Крім того, поліцейські спрямовували свою професійну діяльність на забезпечення безпеки (відсутність неприпустимого ризику, пов'язаного $з$ можливістю завдання будь-якої шкоди для життя, здоров'я та майна громадян, а також для навколишнього природного середовища) ${ }^{6}$. Безпека - це відсутність загрози життю, здоров'ю людей, майну, тваринам, рослинам i довкіллю, що перевищує граничний ризик ${ }^{7}$.

У Законодавстві України не закріплено імперативної норми щодо необхідності фіксування факту безпосереднього контакту поліцейських із населенням (точніше із представниками населення, оскільки неможливо водночас контактувати 3 усіма особами, які проживають у певній територіальній одиниці).

У Наказі МВС України від 3 червня 2020 р. № 431 у п. 2 зазначено, що додаткові виплати здійснюються поліцейським, які перебувають

5 Про затвердження Положення про службу дільничних інспекторів міліції в системі Міністерства внутрішніх справ України : Наказ МВС України від 11.11.2010 № 550 // БД «Законодавство України» / BP України. URL: https://zakon.rada.gov.ua/laws/show/z1219-10 (дата звернення: 30.08.2020). Втратив чинність.

6 Про заходи щодо виконання постанови Кабінету Міністрів України від 05.05.1997 № 409 «Про забезпечення надійності й безпечної експлуатації будівель, споруд та інженерних мереж» : наказ Держ. комітету будівництва, архітектури та житлової політики України та Держ. комітету по нагляду за охороною праці України від 27.11.1997 № 32/288 // БД «Законодавство України» / ВР України. URL: https://zakon.rada.gov.ua/laws/ show/z0423-98 (дата звернення: 30.08.2020). Втратив чинність.

7 Про затвердження Положення про систему управління безпекою руху поїздів у Державній адміністрації залізничного транспорту України : Наказ М-ва інфраструктури України від 01.04.2011 № 27 // БД «Законодавство України» / BP України. URL: https://zakon.rada.gov.ua/laws/ show/z0729-11 (дата звернення: 30.08.2020). 
відповідно на штатних посадах в органах (підрозділах) Національної поліції України. Це вказує на те, що всі поліцейські мають право на додаткову соціальну гарантію у вигляді доплати до грошового забезпечення, адже поліцейським не доводилися до відома жодні обмеження та заборони щодо надання поліцейських послуг у відповідних сферах.

Необхідно враховувати, що норми та гарантії оплати праці, визначені законодавством для працівників підприємств, установ, організацій усіх форм власності, $€$ мінімальними державними гарантіями нормального соціально-економічного забезпечення поліцейських, чия праця має додаткові ризики, в тому числі зумовлені поширенням пандемії в державі та світі, викликаної коронавірусною інфекцією. Така доплата за виконання обов'язків поліцейського, прямо визначених у ст. 18 Закону України «Про Національну поліцію» та у функціональних обов'язках, $є$ соціальною гарантією на забезпечення гідних умов життя і збереження здоров'я, яке додатково зазнавало загроз під час карантину.

Нагадаємо, що відповідно до п. 2 Постанови Кабінету Міністрів України «Про грошове забезпечення поліцейських Національної поліції» від 11 листопада 2015 р. № $988^{1}$ виплата грошового забезпечення поліцейським Національної поліції та курсантам закладів вищої освіти МВС України зі специфічними умовами навчання здійснюється в порядку, затвердженому Міністерством внутрішніх справ. Ця норма $є$ відсильною й обумовлює існування спеціального нормативно-правового акта для унормування порядку (механізму) нарахування та виплати грошового забезпечення поліцейським.

Порядок та умови виплати грошового забезпечення поліцейським Національної поліції визначено Порядком та умовами виплати грошового забезпечення поліцейським Національної поліції та курсантам вищих навчальних закладів МВC із специфічними умовами навчання, затвердженим Наказом МВС України від 6 квітня 2016 р. № 260². Грошове забез-

1 Про грошове забезпечення поліцейських Національної поліції : Постанова Кабінету Міністрів України від 11.11.2015 № 988 // БД «Законодавство України» / BP України. URL: https://zakon.rada.gov.ua/laws/show/988-2015-п (дата звернення: 30.08.2020).

2 Про затвердження Порядку та умов виплати грошового забезпечення поліцейським Національної поліції та здобувачам вищої освіти закладів вищої освіти із специфічними умовами печення поліцейських визначається залежно від посади, спеціального звання, стажу служби в поліції, інтенсивності й умов служби, кваліфікації, наукового ступеня або вченого звання. До складу грошового забезпечення входять: 1) посадовий оклад; 2) оклад за спеціальним званням; 3) щомісячні додаткові види грошового забезпечення (підвищення посадового окладу, надбавки, доплати, які мають постійний характер); 4) премії; 5) одноразові додаткові види грошового забезпечення.

Підставою для виплати грошового забезпечення $\epsilon$ наказ керівника (начальника) органу, закладу, установи Національної поліції про призначення на посаду поліцейського відповідно до номенклатури посад і встановлення конкретного розміру окладів, надбавок, доплат.

Упродовж карантину поліцейські виконували завдання, що стоять перед Національною поліцією та визначені у ст. 2 Закону України «Про Національну поліцію», в тому числі завдання в межах функціональних підсистем єдиної державної системи цивільного захисту, спрямовані на профілактику та протидію поширенню коронавірусної інфекції, вжиття заходів щодо правового супроводу притягнення правопорушників до адміністративної відповідальності за порушення правил карантину.

\section{Висновки}

Ураховуючи викладене, доходимо висновку (який, на наш погляд, є обгрунтованим та належним чином умотивованим), що поліцейські, незалежно від займаної посади, які в період карантину виконували повноваження поліції та службові (посадові) обов'язки, мають надане і гарантоване державою право на соціальні гарантії в умовах, що ускладнюють надання поліцейських послуг, зумовлених поширенням коронавірусної інфекції, а саме на додаткові доплати до грошового забезпечення на підставі та в розмірах, визначених Постановою Кабінету Міністрів України від 29 квітня 2020 р. № 375.

Переконані, що соціальні гарантії поліцейських, визначені вищим за юридичною силою нормативно-правовим актом, не повинні звужуватися та обмежуватися підзаконними актами, які мають меншу юридичну силу. Додаткові соціальні гарантії поліцейських під час карантину зумовлені не стільки їх

навчання, що здійснюють підготовку поліцейських : Наказ МВС України від 06.04.2016 № 260 // БД «Законодавство України» / BP України. URL: https://zakon.rada.gov.ua/laws/show/z0669-16 (дата звернення: 30.08.2020). 
статусом, скільки тими завданнями та функціями, які поліцейські продовжують виконувати в соціумі, надаючи суспільству й окремим його членам поліцейські послуги, не маючи можливості скористатися тими додатковими гарантіями, які держава запроваджує для усього населення, з метою збереження їх життя і здоров'я від коронавірусної інфекції.

Вважаємо, що під час ухвалення урядом України відповідного рішення, зазначеного в Постанові Кабінету Міністрів України від 29 квітня 2020 р. № 375, слід викласти норму таким чином, щоб уникнути невиправданих умов для звуження соціальних гарантій для працівників окремих професій, у тому числі поліцейських, унеможлививши застосування представниками центральних органів виконавчої влади, їх територіальних підрозділів адміністративного розсуду, який призводить до звуження державних соціальних гарантій у вигляді додаткових доплат до грошового забезпечення поліцейським.

Зниження рівня соціальних гарантій шляхом позбавлення додаткових доплат поліцейським за надання поліцейських послуг під час карантину зумовлює неоднаковий статус поліцейських, що обумовлений не об’єктивними факторами, а виключно суб'єктивним.

У наявних умовах загострення коронавірусної інфекції і тих негативних наслідків, які остання становить для життя та здоров'я людей, держава повинна всіляко підтримувати і сприяти соціальним гарантіям захисту осіб, які продовжують надавати поліцейські послуги населенню.

\section{Список бібліографічних посилань}

1. Право соціального забезпечення в Україні : підручник / О. М. Ярошенко, Г. О. Барабаш, Н. М. Вапнярчук та ін. ; за ред. О. М. Ярошенка. 4-те вид., перероб. і допов. Харків : Право, 2015. 458 с.

2. Марчук М. І. Право на працю у конституційно-правовій доктрині України // Сфера дії трудового права та права соціального забезпечення : матеріали V Всеукр. наук.-практ. конф. (м. Харків, 28 жовт. 2016 р.) / МВС України, Харків. нац. ун-т внутр. справ. Харків, 2016. С. 191-194.

3. Бортник С. М. Проблеми правового регулювання трудових прав поліцейських підзаконними нормативно-правовими актами. Науковий вісник публічного та приватного права. 2017. Вип. 6, т. 3. C. 26-31.

4. Лемеш Д. Л. Адміністративно-правовий статус працівників поліції в Україні : автореф. дис. ... канд. юрид. наук : 12.00.07. Київ, 2016. 20 с.

5. Малента В. С. Неофіційне тлумачення норм права : автореф. дис. ... канд. юрид. наук : 12.00.01. Київ, 2010. 16 с.

6. Самбор М. А. Склад адміністративного правопорушення щодо порушення правил карантину людей. Вісник Луганського державного університету внутрішніх справ імені Е. О. Дідоренка. 2020 . № 2 (90). С. 155-170.

7. Зозуля І. В. Поліцейські послуги в законодавстві України та на практиці. Форум права. 2019. № 3. C. 21-38. DOI: http://doi.org/10.5281/zenodo.3362208.

8. Пам'ятка працівника Національної поліції України. Інформаційно-довідкові матеріали $з$ питань професійного спілкування поліцейських / уклад.: І. В. Клименко, Д. В. Швець, О. О. Євдокімова, Я. С. Посохова. Харків : Харків. нац. ун-т внутр. справ, 2017. 52 с.

Надійшла до редколегії 11.09.2020

\section{САМБОР Н. А. ДОПОЛНИТЕЛЬНАЯ ДОПЛАТА К ДЕНЕЖНОМУ ОБЕСПЕЧЕНИЮ КАК СОЦИАЛЬНАЯ ГАРАНТИЯ ПРАВ ПОЛИЦЕЙСКИХ ВО ВРЕМЯ КАРАНТИНА В УКРАИНЕ}

Исследованы особенности правового регулирования установления и выплаты дополнительной доплаты к денежному обеспечению во время карантина для полицейских. Проанализированы нормативно определенные основания для дополнительной выплаты и фактическое обоснование применения таких выплат для полицейских. Обоснованно правовую позицию по поводу необходимости дополнительных выплат для всех полицейских, исходя из задач, которые стоят перед органами Национальной полиции, и предоставления полицейскими полицейских услуг населению Украины.

Ключевые слова: карантин, полиция, дополнительные доплаты, денежное обеспечение, полищейские услуги, правопорядок, жизнеобеспечения.

\section{SAMBOR M. A. FRINGE BENEFITS TO CASH COLLATERAL AS A SOCIAL GUARANTEE OF POLICE RIGHTS DURING QUARANTINE IN UKRAINE}

The peculiarities of the legal regulation for establishing and paying fringe benefits to the cash collateral during quarantine for police officers have been studied. The normatively defined 
grounds for fringe benefits and the actual substantiation of the application of such payments for police officers have been analyzed. The legal position of the need for fringe benefits for all police officers has been substantiated, based on the tasks facing the National Police and the provision of police services to the population of Ukraine.

A comprehensive understanding of the tasks of the National Police allows us to conclude that the exercise of police powers is carried out through the provision of police services, which involves direct contact of police officers with the public or individual citizens. Under such conditions, the only possible conclusion is that every police officer during quarantine is entitled to fringe benefits to the cash collateral.

Social guarantees for police officers, which are defined by the highest regulatory act according to legal force, should not be narrowed and limited to bylaws that have lower legal force. Additional social guarantees for police officers during quarantine are determined not so much by their status as by the tasks and functions that police officers continue to perform in society, providing police services to society and its individual members without being able to take advantage of additional guarantees provided by the state to the citizens, the whole population in order to save their lives and health from coronavirus infection.

Reducing the level of social guarantees by depriving police officers of fringe benefits for providing police services during quarantine causes different status of police officers, which is mainly stipulated not to objective factors, but only subjective, and also affects the efficiency of police services and security of police officers.

Key words: quarantine, police, fringe benefits, cash collateral, police services, law and order, life sustenance. 